\title{
IMPLEMENTASI SISTEM INFORMASI KESEHATAN (SIK) PUSKESMAS DI KABUPATEN KONAWE SELATAN TAHUN 2018
}

\author{
Serly Astrini ${ }^{1}$, Reza Aril Ahri ${ }^{2}$, Samsualam ${ }^{3}$ \\ ${ }^{1}$ Pascasarjana Universitas Musim Indonesia Makassar \\ ${ }^{2}$ Pascasarjana Universitas Musim Indonesia Makassar \\ ${ }^{3}$ Pascasarjana Universitas Musim Indonesia Makassar
}

Alamat korespondensi : (serlyastrini@gmail.com/081286910575)

\begin{abstract}
ABSTRAK
Sistem Informasi Kesehatan (SIK) adalah seperangkat tatanan yang meliputi data, informasi, indikator, prosedur, perangkat, teknologi dan sumber daya manusia yang saling berkaitan. Tujuan penelitian ini untuk menggali informasi mendalam mengenai implementasi Sistem Informasi Kesehatan (SIK) puskesmas ditinjau dari elemen input, proses, output di kabupaten Konawe Selatan. Jenis Penelitian ini adalah penelitian kualitatif dengan pendekatan studi kasus. Subjek penelitian terdiri dari 8 orang informan biasa dan 1 orang informan kunci. Hasil penelitian bahwa implementasi SIK puskesmas ditinjau dari elemen input: kualitas data masih ada puskesmas yang telat mengirim data; kualitas dan kuantitas Sumber Data Manusia (SDM) masih kurang; sarana prasarana masih kurang; alokasi anggaran dalam pelaksanaannya menggunakan dana yang bersumber dari APBD dan BOK. Implementasi SIK puskesmas ditinjau dari elemen proses: pengolahan data menggunakan sistem komputerisasi; pemeliharaan yang dilakukan tidak rutin setiap tahun; konsistensi dalam pengiriman data belum konsisten; pelaporan data dilakukan setiap tanggal 5. Implementasi SIK puskesmas ditinjau dari elemen output: sistem informasi di kabupaten Konawe Selatan untuk data yang dihasilkan digunakan untuk perencanaan pelaksanaan kegiatan untuk kedepannya. Kesimpulan: Hal ini berarti bahwa implementasi SIK puskesmas di kabupaten Konawe Selatan ditinjau dari elemen input, proses dan output secara umum belum baik sehingga masih perlu perbaikan.
\end{abstract}

Kata Kunci: Sistem Informasi Kesehatan (SIK)

\section{PENDAHULUAN}

Menurut World Health Organization (WHO), Sistem Informasi Kesehatan (SIK) adalah salah satu dari 6 building block atau merupakan komponen utama dalam suatu sistem kesehatan. Keenam komponen (buildingblock) sistem kesehatan tersebut yaitu service delivery (pelaksanaan pelayanan kesehatan), medical product, vaccine, and technologies (produk medis, vaksin, dan teknologi kesehatan), health worksforce (tenaga medis), health system financing (sistem pembiayaan kesehatan), health information system (sistem informasi kesehatan), leadership and governance (kepemimpinan dan pemerintah).

Seiring dengan perkembangan di bidang kesehatan, pemerintah menyadari pentingnya data dan informasi yang ada di bidang kesehatan, sehingga berupaya untuk mengintegrasikan data dan informasi tiap-tiap program kesehatan maka pemerintah menyusun suatu sistem yang disebut sebagai Sistem Kesehatan Nasional (SKN). SKN merupakan bentuk dan cara penyelenggaraan pembangunan kesehatan dalam berbagai upaya guna menjamin tercapainya pembangunan kesehatan yang sesuai dengan Undang-undang Dasar 1945 (Departemen Kesehatan RI, 2009).

Teknologi Informasi (TI) yang terus berkembang mendorong Dinas Kesehatan di daerah melakukan pengelolaan dan pengembangan SIK sesuai dengan kemampuan masing-masing. Pemerintah Daerah mengembangkan sistem informasi yang dapat mengintegrasikan dan memfasilitasi proses pengumpulan data dan pengolahan data sehingga dapat mendukung peranan sistem informasi dalam pelayanan kesehatan (Pusat Data dan Informasi, 2011).

Kabupaten Konawe Selatan merupakan salah satu bagian daerah Provinsi Sulawesi Tenggara yang terletak di Jazirah Tenggara Pulau Sulawesi. Luas wilayah daratan Kabupaten Konawe Selatan $451.420 \mathrm{Ha}$ atau $11,83 \%$ dari luas wilayah daratan Sulawesi Tenggara. Kabupaten Konawe Selatan terdiri dari 25 kecamatan dengan 361 desa dan kelurahan. Jumlah puskesmas di kabupaten Konawe Selatan terdiri dari 23 puskesmas. Sejak agustus 2017, dinas kesehatan kabupaten konawe selatan membuat inovasi dengan membuat aplikasi yang bernama 
"Simpel Sehat" dengan tujuan dari aplikasi tersebut untuk memudahkan tiap-tiap puskesmas untuk mengirimkan datanya langsung ke dinas kesehatan kabupaten Konawe Selatan. Hingga saat ini, aplikasi tersebut masih dalam tahap pengembangan dan seluruh puskesmas yang ada di kabupaten konawe selatan telah menggunakan aplikasi tersebut. Dalam penerapan sistem informasi kesehatan di kabupaten Konawe Selatan yang bertujuan membantu meningkatkan pelayanan kesehatan, terdapat hambatan-hambatan yang menjadi permasalahan dan memberi pengaruh dalam pelayanan kesehatan. Masalah yang dihadapi tersebut seperti kualitas dan kuantitas SDM yang belum memadai, akses puskesmas yang susah, pengelolaan data yang belum terintegrasi, dan masih banyak penyebab lain yang dapat mempengaruhi penerapan Sistem informasi kesehatan yang efektif di kabupaten Konawe Selatan (Profil Kesehatan Dinas Kesehatan Kabupaten Konawe Selatan, 2017). Berdasarkan uraian di atas penulis ingin melakukan penelitian mengenai "Implementasi Sistem Informasi Kesehatan (SIK) Puskesmas di Kabupaten Konawe Selatan".

\section{BAHAN DAN METODE}

\section{Lokasi Penelitian}

Lokasi Penelitian terletak di puskesmas dan dinas kesehatan Kabupaten Konawe Selatan Provinsi Sulawesi Tenggara bulan November sampai Desember 2018. Puskesmas di kabupaten Konawe Selatan berjumlah 23 puskesmas namun peneliti hanya memilih 8 puskesmas dikarenakan pelaksanaan SIK di 23 puskesmas tersebut memiliki karakteristik yang sama yaitu menggunakan sistem komputerisasi. Peneliti memilih 8 puskesmas berdasarkan jalur dan jarak puskesmas yang satu dengan yang lainnya.

\section{Informan Penelitian}

Pemilihan informan dilakukan secara Purposive Sampling (kriteria ditentukan oleh peneliti) dengan mewawancarai 8 orang informan biasa dan 1 orang informan kunci Pengumpulan data

1. Observasi

2. Wawancara Mendalam

3. Telaah Dokumen

4. Dokumentasi

\section{Teknik Analisis Data}

Data yang diperoleh melalui wawancara mendalam, dalam penelitian ini dianalisis dengan cara analisis data (Content Analysist) dalam penyajian data disajikan dalam bentuk narasi, proses analisis mulai dengan menelaah seluruh data yang tersedia dari berbagai sumber, yaitu dari hasil wawancara, pengamatan yang sudah ditulis dalam catatan lapangan dan dokumentasi.

\section{HASIL PENELITIAN}

1. Implementasi SIK puskesmas ditinjau dari elemen input di kabupaten Konawe Selatan

a. Kualitas Data

Kualitas data dalam sistem informasi kesehatan (SIK) puskesmas di kabupaten Konawe Selatan dari segi ketersediaan, akurat, dan tepat waktu sudah sesuai aturan yang berlaku. Dimana batas pengumpulan data dari tiap puskesmas ke dinas kesehatan kabupaten Konawe Selatan setiap tanggal 5. Namun ada juga puskesmas yang telat dalam mengirim data ke dinas kesehatan, mengirim di atas tanggal 5 bulan berjalan termasuk kategori telat. Hal ini berdasarkan pernyataan informan sebagai berikut:

"Sering sih telat karena adakan laporan itu yang harus dikumpul dari poli KIA, poli umum, poli gigi dikumpulkan itu terutama posbindu online toh kemudian harus kumpulkan datanya itu. Kalau alasannya sih cuma itu karena mereka harus kumpulkan datanya dari 3 poli itu. Tapi nda pernah ji telat sampai tanggal 10 ke atas, biasanya tanggal 6 sudah." (HY, 21 November 2018)

b. SDM

Sumber Daya Manusia (SDM) di puskesmas kabupaten Konawe Selatan terbilang masih kurang dan ada juga pengelola SIK serta petugas pengelola program kesehatan yang merangkap jabatan lain sehingga menghambat dalam proses pengumpulan data. Hal ini sesuai dengan informasi dari informan sebagai berikut:

"ada sebagian kayak di P2 dia itu kayak P2 TB, kusta, HIV, itu 1 orang dia. Misalnya sama seperti diare itu ada bidannya pegang program diare, kemudian bidan desa juga memegang program tipoid toh. Kemudian ada juga yang intinya ada yang pegang kesling jadi bendahara BOK, kemudian ada yang perawat UGD jadi bendahara JKN." (IG, 22 November 2018)

c. Sarana Prasarana

Sarana prasarana di puskesmas kabupaten Konawe Selatan meliputi hardware, software, dan jaringan. Sarana prasarana di puskesmas kabupaten Konawe Selatan masih 
belum memadai. Sehingga hal tersebut juga yang menjadi penghambat dalam pengiriman laporan ke dinas kesehatan. Untuk jaringan internet di puskesmas sebagian mengatakan kurang baik. Hal ini berdasarkan informasi dari informan sebagai berikut:

"kadang kalau listrik padam jaringan hilang disini." (AS, 3 November 2018)

d. Alokasi Anggaran

Anggaran yang digunakan puskesmas di kabupaten Konawe Selatan berasal dari dana BOK untuk pembelian paket data sebesar Rp100.000,- tiap bulan. Hal ini berdasarkan pernyataan informan sebagai berikut:

"kalau kita disini sistem paket itu ditanggung BOK Rp100.000,- per bulan." (AS, 3 November 2018)

2. Implementasi SIK puskesmas ditinjau dari elemen proses di kabupaten Konawe Selatan

a. Pengolahan

Pengolahan data puskesmas kabupaten Konawe Selatan dilakukan dari masingmasing petugas pengelola program kesehatan sebelum dikirim ke dinas kesehatan. Hal ini berdasarkan pernyataan informan sebagai berikut: "pengolahan data secara teknis itu ada di masing-masing programer bersangkutan. Disitu ada perhitungan pencapaian kinerja, kemudian perhitungan program-program yang belum tercapai." (HS, 1 November 2018)

b. Pemeliharaan

Pemeliharaan komputer atau laptop puskesmas dilakukan tidak rutin, hanya saat mengalami gangguan atau kerusakan lalu dilakukan pemeliharaan. Hal tersebut berdasarkan informasi dari informan sebagai berikut:

"kalau untuk pemeliharaannya kita puskesmas ada pertahun kayak kalibrasi saja tetapi itupun jarang, biasanya 1 tahun sekali. Rusak pi baru bisa kita komplain ke dinas." (NS, 19 November 2018)

c. Konsistensi

Konsistensi dalam pengentrian data puskesmas ke aplikasi Simpel Sehat yang dilakukan tidak langsung lengkap semua data dimasukkan tetapi sesuai dengan data apa yang telah siap untuk dikirmkan. Hal ini berdasarkan informasi dari informan sebagai berikut:

"kan kita minimal itu di atas 50\% mengirim dulu lah, nanti keterlambatan itu bisa kita minimalisirlah maksudnya toh." (AS, 3 November 2018)

\section{d. Pelaporan}

Batas pelaporan data puskesmas ke dinas kesehatan kabupaten Konawe Selatan setiap tanggal 5 bulan berjalan. Untuk puskesmas yang mengirim laporannya diatas tanggal tersebut termasuk kategori terlambat dan diberikan sanksi berupa teguran dari kepala puskesmas.

3. Implementasi SIK puskesmas ditinjau dari elemen output di kabupaten Konawe Selatan

a. Sistem Informasi

Sistem informasi di puskesmas
kabupaten Konawe menggunakan aplikasi Simpel Sehat dinilai sudah sangat membantu puskesmas dalam mengirimkan laporannya ke dinas kesehatan kabupaten Konawe Selatan. Hal ini berdasarkan informasi dari informan sebagai berikut:

"sampai sejauh ini sudah membantu sekali, bagus sekali malah terutama yang jarak tempuhnya jauh dari dinas." (HS, 1 November 2018)

\section{PEMBAHASAN}

1. Implementasi SIK puskesmas ditinjau dari elemen input di kabupaten Konawe Selatan a. Kualitas Data

Kualitas data adalah level data yang menyatakan data tersebut akurat (accurate), lengkap (complete), timely (update), konsisten (consistent) sesuai dengan semua kebutuhan peraturan bisnis dan relevan (Mosley, 2008). Sistem Informasi Kesehatan (SIK) puskesmas di kabupaten Konawe Selatan dari segi kualitas data sudah baik namun masih ada puskesmas yang kadang telat dalam mengirimkan datanya. Hal tersebut disebabkan oleh beberapa faktor, diantaranya disebabkan oleh programer puskesmas yang telat mengumpulkan datanya ke pengelola SIK puskesmas. Programer yang dimaksud adalah petugas pengelola program kesehatan, misalnya petugas pengelola program TB, DBD, dan lain-lain.

Selain itu juga masalah jaringan yang kurang baik di beberapa puskesmas hingga masalah aplikasi yang mengalami gangguan dan hal tersebut yang menghambat dalam pengirimaan data puskesmas ke dinas kesehatan melalui aplikasi Simpel Sehat. Hal ini sejalan dengan penelitian yang dilakukan oleh (Isnaini, 2017) 
mengenai efektivitas pelaksanaan sistem informasi kesehatan online pada dinas kesehatan kabupaten Rokan Hilir, diketahui bahwa masih banyaknya puskesmas yang tidak melaporkan data dan terlambat melaporkan datanya ke dinas kesehatan kabupaten Rokan Hilir. Ketidaksadaran sumber daya manusia merupakan penghambat dari berhasil atau tidaknya pelaksanaan Sistem Informasi Kesehatan Online tersebut serta masalah lain yaitu jaringan komunikasi yang ada di kawasan dinas kabupaten Rokan Hilir tidak stabil, sehingga terganggunya proses pengiriman data ke dinas kesehatan provinsi. Berdasarkan kondisi dan permasalahan tersebut jika pemerintah kabupaten tidak menangani dengan serius, maka akan berpotensi menyebabkan terganggunya proses, output dan outcame dalam implementasi Sistem Informasi Kesehatan puskesmas di kabupaten Konawe Selatan.

b. SDM

Salah satu faktor yang menentukan keberhasilan penerapan sebuah aplikasi sistem informasi adalah ketersediaan SDM yang memadai baik dari sisi kualitas maupun kuantitasnya. Kuantitas SDM di puskesmas kabupaten Konawe Selatan masih terbilang kurang, terlihat dari banyaknya pegawai puskesmas yang juga sebagai pengelola program kesehatan lainnya dikarenakan kurangnya tenaga kesehatan. Hal ini tidak sesuai dengan Peraturan Menteri Kesehatan No. 75 Tahun 2014 tentang Puskesmas, pasal 16 ayat (2) yang berbunyi: "jenis dan jumlah tenaga kesehatan dan tenaga non kesehatan dihitung berdasarkan analisis beban kerja, dengan mempertimbangkan jumlah pelayanan yang diselenggarakan, jumlah penduduk dan persebarannya, karakteristik wilayah kerja, luas wilayah kerja, ketersediaan fasilitas pelayanan kesehatan tingkat pertama lainnya di wilayah kerja, dan pembagian waktu kerja." Hal ini juga tentunya yang menjadi salah satu penghambat dalam pengumpulan data dari petugas pengelola program kesehatan ke pengelola SIK puskesmas dan juga pengiriman laporan puskesmas ke dinas kesehatan kabupaten Konawe Selatan. c. Sarana Prasarana

Sarana prasarana dalam menunjang pelaksanaan SIK di puskesmas meliputi komputer, printer, dan ATK (Alat Tulis kantor). Namun untuk komputer masih ada puskesmas di kabupaten Konawe Selatan yang masih kekurangan. Ketersediaan komputer sebagai sarana mengentri data tidak boleh diabaikan. Seluruh puskesmas di kabupaten Konawe Selatan sudah dilengkapi dengan perangkat komputer. Meski demikian, masih ada puskesmas yang masih kekurangan dilihat dari masih adanya puskesmas yang hanya memiliki 2 komputer dan 1 laptop puskesmas untuk mengolah data, kalaupun komputer tersedia kondisinya tidak mendukung untuk menjalankan aplikasi Simpel Sehat. Kondisi seperti ini tentu akan menghambat dalam ketepatan waktu pelaporan data puskesmas ke dinas kesehatan Kabupaten Konawe Selatan serta berpengaruh pada kepatuhan petugas dalam mengentri data ke aplikasi Simpel Sehat.

d. Alokasi Anggaran

Untuk alokasi anggaran sistem informasi kesehatan puskesmas di kabupaten Konawe Selatan dalam pelaksanaannya menggunakan dana yang bersumber dari APBD dan BOK. Hal ini sesuai dengan PP No. 46 Tahun 2014 tentang SIK pasal 72 ayat (2) yang mengatakan bahwa pendanaan penyelenggaraan Sistem Informasi Kesehatan yang dikelola oleh Pemerintah Daerah, termasuk Fasilitas Pelayanan Kesehatan milik Pemerintah Daerah bersumber dari Anggaran Pendapatan dan Belanja Daerah dan/atau sumber lain yang sah sesuai dengan ketentuan peraturan perundang-undangan.

Dalam hal penyediaan anggaran pendukung implementasi dan pemeliharaan sistem informasi kesehatan di puskesmas kabupaten Konawe Selatan, anggaran sudah disediakan bergabung dengan anggaran pemeliharaan perangkat komputer dan paket data. Demikian juga di tingkat dinas kesehatan, alokasi anggaran untuk pemeliharaan website dan pengadaan sarana perangkat komputer untuk puskesmas. Untuk puskesmas yang menggunakan paket data untuk jaringan internet dalam mengirimkan data puskesmas ke dinas 
kesehatan mengunakan dana BOK sebesar Rp100.000,- per bulan yang diklaim ke dinas kesehatan.

2. Implementasi SIK puskesmas ditinjau dari elemen proses di kabupaten Konawe Selatan

a. Pengolahan

Pengolahan data merupakan
bagian sistem yang melakukan
perubahan, pembentukan dan perubansformasi dari masukan menjadi keluaran (Yakub, 2012). Strong et al. (1997) dalam Lee dan Strong (2003), menyatakan bahwa tujuan pengolahan data adalah untuk menghasilkan data yang dapat dipakai oleh penggunanya.

$$
\text { Menurut Sutabri (2005) }
$$

pengolahan data dapat dilakukan secara manual ataupun dengan bantuan komputer. Pengolahan data di puskesmas kabupaten Konawe Selatan menggunakan sistem komputerisasi yang dimulai dari masing-masing petugas pengelola program kesehatan yang mengolah data dari masingmasing unit pelayanan baik itu yang dilakukan di luar gedung maupun di dalam gedung. Setelah itu diserahkan ke pengelola SIK puskesmas dalam hal ini yang bertanggung jawab dalam proses pengiriman data ke dinas kesehatan kabupaten Konawe Selatan. Saat petugas SIK puskesmas mengolah data yang dikumpulkan dari masingmasing petugas pengelola program kesehatan, seringkali ada data-data yang masih kurang lengkap seperti tanggal yang tidak sesuai, nama bulan yang belum terganti dan juga belum ditanda tangani. Pengolahan data yang dilakukan oleh pengelola SIK puskesmas berupa pengecekan kembali data yang akan dikirimkan, penginputan ke aplikasi Simpel Sehat, serta bersama petugas pengelola program kesehatan melakukan analisis ketercapaian program dan mengevaluasinya bersama-sama.

b. Pemeliharaan

Pemeliharaan yang dilakukan oleh puskesmas di kabupaten Konawe Selatan yaitu pemeliharaan komputer yang dilakukan tidak rutin setiap tahun yang dilakukan jika komputer atau laptop puskesmas mengalami gangguan atau kerusakan sehingga perlu perbaikan atau pemeliharaan. Hal tersebut juga berpengaruh dalam menginput data atau mengirim data melalui komputer atau laptop puskesmas disebabkan karena komputer menjadi lambat merespon sehingga diperlukan pemeliharaan atau perbaikan. Sedangkan untuk pemeliharaan website dilakukan oleh dinas kesehatan setahun sekali. Tujuannya untuk menambah daya tampung data, pembaharuan item di aplikasi dan sebagainya.

c. Konsistensi

Konsistensi dalam pengentrian data puskesmas ke aplikasi Simpel Sehat berarti memasukkan data setiap bulan, tepat waktu (data dimasukkan sebelum tanggal 5) dan lengkap (semua field dalam menu aplikasi terisi). Tetapi ternyata tidak semua puskesmas dapat konsisten melaksanakannya. Masih terdapat puskesmas yang telat dalam mengirimkan laporannya ke dinas kesehatan kabupaten Konawe Selatan yaitu diatas tanggal 5 bulan berjalan dan juga pengiriman laporan puskesmas ke aplikasi Simpel Sehat tidak dilakukan sekaligus tetapi berdasakan data dari petugas pengelola program kesehatan yang telah selesai dan telah siap dikirimkan dengan melihat lembar ceklist berupa daftar laporan apa saja yang harus dikirimkan melalui aplikasi Simpel Sehat.

d. Pelaporan

Perkembangan

teknologi informasi yang sangat cepat merupakan jawaban untuk mendapatkan informasi dalam bentuk pelaporan yang cepat. Namun permasalahan yang terjadi yaitu masih terdapat puskesmas yang terlambat melaporkan datanya ke dinas Kesehatan kabupaten Konawe Selatan. Batas pelaporan data puskesmas ke dinas kesehatan kabupaten Konawe Selatan setiap tanggal 5 setiap bulannya tetapi masih ada juga puskesmas yang pada batas tanggal tersebut belum mengirimkan laporannya ke aplikasi Simpel Sehat, sehingga data yang masuk ke dinas kesehatan kabupaten Konawe Selatan di atas tanggal tersebut dianggap terlambat. Untuk masing-masing puskemas yang telat mengirimkan datanya diberi sanksi berbeda-beda berdasarkan peraturan dari masing-masing kepala puskesmas. Ada yang hanya diberi teguran, pemotongan gaji, dan ada juga sanksi yang diberikan langsung untuk petugas pengelola program kesehatan bila telat mengumpulkan laporannya ke pengelola SIK puskesmas maka 
diharuskan ke dinas kesehatan kabupaten Konawe selatan untuk mengumpulkan secara langsung laporannya.

3. Implementasi SIK puskesmas ditinjau dari elemen output di kabupaten Konawe Selatan

a. Sistem Informasi

Output dalam Sistem Informasi Kesehatan (SIK) puskesmas di kabupaten Konawe Selatan yaitu menghasilkan sistem informasi. Menurut (Husein, 2000) sistem informasi adalah seperangkat komponen yang saling berhubungan dan berfungsi mengumpulkan, memproses, menyimpan dan mendistribusi informasi untuk mendukung pengambilan keputusan dan pengawasan dalam organisasi. Sistem informasi di puskesmas kabupaten Konawe Selatan terbilang cukup baik karena untuk pengiriman laporan puskesmas ke dinas kesehatan telah menggunakan aplikasi simpel sehat, aplikasi yang di buat dari pihak dinas kesehatan. Dalam penggunaannya sudah sangat membantu puskesmas yang ada di kabupaten konawe Selatan sebab jarak antar masing-masing puskesmas dengan dinas kesehatan termasuk jauh sehingga dengan adanya aplikasi tersebut dapat menghemat waktu, biaya serta tenaga dalam hal pengiriman laporan ke dinas kesehatan. Keluaran atau output merupakan hasil atau produk dari sistem informasi yang berupa informasi dan berbentuk dokumentasi atau laporan (Fatta, 2007). Data yang dihasilkan setiap bulannya digunakan oleh puskesmas dan dinas kesehatan untuk perencanaan pelaksanaan kegiatan kedepannya.

\section{KESIMPULAN}

1. Implementasi SIK puskesmas ditinjau dari elemen input: kualitas data masih ada puskesmas yang telat mengirim data; kualitas dan kuantitas SDM masih kurang; sarana prasarana masih kurang terlihat dari masih adanya puskesmas yang kekurangan komputer; dan alokasi anggaran dalam pelaksanaannya menggunakan dana yang bersumber dari APBD dan BOK.

2. Implementasi SIK puskesmas ditinjau dari elemen proses: pengolahan data menggunakan sistem komputerisasi; pemeliharaan yang dilakukan tidak rutin setiap tahun; konsistensi dalam pengiriman data belum konsisten; pelaporan data dilakukan setiap tanggal 5 namun dalam pelaksanaannya masih terdapat puskesmas yang mengirim di atas tanggal tersebut.

3. Implementasi SIK puskesmas ditinjau dari elemen output: sistem informasi di kabupaten Konawe Selatan untuk data yang dihasilkan digunakan untuk perencanaan pelaksanaan kegiatan untuk kedepannya.

\section{SARAN}

1. Kuantitas Sumber Daya Manusia (SDM) yang ada di puskesmas kabupaten Konawe Selatan agar didistribusikan secara merata sesuai kebutuhan dan beban kerja.

2. Keamanan aplikasi Simpel Sehat perlu ditingkatkan lagi sehingga mengurangi terjadinya gangguan pada aplikasi tersebut.

3. Pengadaan komputer bagi puskesmas yang masih kekurangan.

\section{DAFTAR PUSTAKA}

Pusat Data dan Informasi. Kementerian Kesehatan. 2011

Profil Kesehatan Dinas Kesehatan Kabupaten Konawe Selatan Tahun 2017.

Mosley M. 2008. The Dama Dictionary of Data Management: Over 800 Terms Defined. Norwood: Technics Publications Llc.

Isnaini. 2017. Efektivitas Pelaksanaan Sistem Informasi Kesehatan Online Pada Dinas Kesehatan Kabupaten Rokan Hilir. JOM FISIP (Online) Vol. 4, No. 2.

Peraturan Menteri Kesehatan Republik Indonesia Nomor 75 Tahun 2014 tentang Pusat Kesehatan Masyarakat. Jakarta. Menteri Kesehatan.

Peraturan Pemerintah Republik Indonesia Nomor 46 Tahun 2014 tentang Sistem Informasi Kesehatan. Jakarta. Presiden Republik Indonesia.

Yakub. 2012. Pengantar Sistem Informasi. CV. Graha Ilmu : Yogyakarta. 
Lee, Y. W., \& Strong, D. M. (2003). Knowing-Why About Data Processes and Data Quality. Journal of Management Information Systems.

Sutabri, Tata. 2012. Konsep Sistem Informasi. Andi Offset: Yogyakarta.

Husein F.M, Wibowo A. 2000. Sistem Informasi Manajemen. UPP AMP YKPN: Yogyakarta.

Fatta H. 2007. Analisis dan Perancangan Sistem Informasi. CV. Andi Offset: Yogyakarta 